\title{
Assessment of depression in elderly with systemic hypertension
}

\author{
Avaliação da depressão em idosos com hipertensão arterial sistêmica \\ Evaluación de la depresión en ancianos con hipertensión arterial sistémica
}

Patrícia Costa dos Santos da Silva ${ }^{1}$, Lidiane Aparecida Monteiro ${ }^{2}$, Alessandra Domingues da Silva Graciano ${ }^{3}$, Fábio de Souza Terra ${ }^{2}$, Eugenia Velludo Veiga ${ }^{1}$

We aimed to evaluate the presence of depression, the ability to perform activities of daily living, and the cognitive function of elderly with hypertension registered in a unit of the family health strategy. A descriptive-quantitative research conducted in Minas Gerais, Brazil, from December 2011 to January 2012, with 172 elderly patients, using a characterization instrument; the Yesavage Geriatric Depression Scale; the Katz Activities of Daily Living Scale; and the Mini-Mental State Examination. We found depressive symptoms in $30.2 \%$ of the sample, $93 \%$ of the elderly were classified as independent, $2.2 \%$ presented partial dependence, and $4.8 \%$, total dependence. By associating the variables "ability to perform activities of daily living" and "depression", we found a statistically significant difference. Thus, we concluded that elderly patients with hypertension present depressive symptoms in a percentage higher than that found in the general population and that most have the ability to perform activities of daily living.

Descriptors: Hypertension, Aged, Depression, Geriatric Assessment; Geriatric Nursing.

Objetivou-se avaliar a presença de depressão, a capacidade para realizar as atividades da vida diária e a função cognitiva de idosos hipertensos cadastrados em uma unidade de estratégia de saúde da família. Pesquisa descritiva/quantitativa, realizada em Minas Gerais, Brasil, de dezembro de 2011 a janeiro de 2012, com 172 idosos, utilizando-se um instrumento de caracterização, Escala de Depressão Geriátrica de Yesavage, Escala de Atividades de Vida Diária de Katz e o Mini-Exame do Estado Mental. Foram encontrados sintomas de depressão em 30,2\% da amostra, 93\% dos idosos foram classificados como independentes; $2,2 \%$ apresentaram dependência parcial e 4,8\%, dependência total. Ao associar as variáveis "capacidade para realizar as atividades da vida diária" e "depressão", constatou-se que houve diferença estatisticamente significativa. Pôde-se concluir que os idosos hipertensos apresentam sintomas depressivos em uma porcentagem superior àquela encontrada na população geral, e a maioria apresenta capacidade para realizar as atividades da vida diária.

Descritores: Hipertensão; Idoso; Depressão; Avaliação Geriátrica; Enfermagem Geriátrica.

El objetivo fue evaluar la presencia de depresión, la capacidad de realizar actividades diarias y la función cognitiva de ancianos hipertensos de una unidad de estrategia de salud familiar. Investigación descriptiva/cuantitativa, en Minas Gerais, Brasil, de diciembre de 2011 a enero de 2012, con 172 pacientes, utilizándose instrumento de caracterización, Escala de Depresión Geriátrica de Yesavage, Escala de Actividades de Vida Diaria de Katz y Mini Examen del Estado Mental. Se encontraron síntomas depresivos en 30,2\% de la muestra, 93\% de los ancianos fueron calificados como independientes, 2,2\% presentaron dependencia parcial y 4,8\% dependencia total. Al asociar las variables "capacidad para realizar las actividades de la vida diaria" y "depresión", hubo diferencia estadísticamente significativa. Los ancianos hipertensos presentaron síntomas depresivos en porcentaje superior a la observada en la población general, y la mayoría poseía capacidad de realizar actividades de vida diaria.

Descriptores: Hipertensión, Anciano, Depresión, Evaluación Geriátrica; Enfermería Geriátrica.

\footnotetext{
${ }^{1}$ Escola de Enfermagem de Ribeirão Preto, Universidade de São Paulo. Ribeirão Preto, SP, Brazil.

${ }^{2}$ Universidade Federal de Alfenas. Alfenas, MG, Brazil.

${ }^{3}$ Universidade José do Rosário Vellano. Alfenas, MG, Brazil.

Corresponding author: Eugenia Velludo Veiga

Avenida dos Bandeirantes, 3900, Campus Universitário - Monte Alegre. CEP: 14040-902. Ribeirão Preto, SP, Brazil.

E-mail: evveiga@eerp.usp.br
} 


\section{Introduction}

Population aging is a worldwide phenomenon. Among the most populous countries in the world, Brazil has one of the fastest population aging processes, while, at the same time, the fertility levels in the country decreased ${ }^{(1)}$.

The aging process, which is natural in life, brings along changes in individual, family, and social context $^{(2)}$. Such changes in physical and mental aspects can lead the elderly to need help in performing their daily activities previously carried out independently. In addition, there are pathophysiological changes typical of some chronic conditions, such as depression and hypertension.

In recent decades, the literature has suggested the association between depressive disorders and hypertension, with some studies that point the consistency in relation to interactions between such chronic conditions, both in the psychosocial and genetic aspect, and obviously on the fact that depression can be an independent risk factor for hypertension in both men and women ${ }^{(3)}$.

A considerable number of elderly people present depressive symptoms, such as anxiety, low self-esteem, loneliness, insomnia, helplessness, but often without any established therapeutic approach. This has attracted the attention of researchers in order to identify the prevalence and the factors involved in the etiology of depression ${ }^{(4)}$.

Nurses and health professionals who work with elderly patients with hypertension need to acquire knowledge about such conditions, as well as on the aging process, so they can seek results that foster reflection in order to prevent such chronic conditions as much as possible, thereby promoting the health and quality of life in old age.

Therefore, for the elderly to remain actively inserted in society there must be more programs to facilitate early diagnosis, prevention, and control of chronic conditions, especially hypertension and depression.
Given the above, this study aimed to evaluate the presence of depression, the ability to perform activities of daily living, and the cognitive function in elderly patients with hypertension registered in a Family Health Strategy Unit.

\section{Method}

This is a descriptive, cross-sectional, quantitative study conducted in a Family Health Strategy Unit (FHSU) of a municipality located in the South region of the State of Minas Gerais, Brazil.

The study population consisted of 196 patients, both male and female, registered on the Hiperdia system of this FHSU. Hiperdia is a program instituted by the Ministry of Health to register and accompany the two most prevalent chronic conditions in Brazil, hypertension and diabetes mellitus. Additionally, it also promotes the reduction of morbidity and mortality related to these conditions, developing actions for support and reorganization of the health system to promote the improvement of care for patients with these diseases in all outpatient units of the Unified Health System ${ }^{(5)}$.

We used the following inclusion criteria: people aged 60 years and older; registered in the abovementioned service where the study took place; and have a medical diagnosis of hypertension. We excluded the elderly who were unable to answer the questionnaire; those missing after three contact attempts; those who moved away; and those hospitalized. Through these criteria, we excluded 24 of the 196 elderly due to death, change of address, travel, admission, or refusal to participate in the study, totaling 172 seniors.

For data collection, we used a semi-structured form with 10 questions on socio-demographic data. To assess depression, we applied a global freely used scale: the Geriatric Depression Scale in the short version of Yesavage (GDS-15), which is widely implemented in studies and validated as an assessment instrument for depression in elderly 
patients. It consists of a test to detect depressive symptoms, with 15 closed questions, in which the result of 5 or more points indicates the presence of depression, and a score equal to or greater than 11 represents severe depression ${ }^{(6-7)}$.

To assess the ability to perform basic activities of daily living, we used the Katz Activities of Daily Living (ADL) Scale. ADLs are those associated with self-care, in other words, they are key activities to maintain independence. This instrument contains six questions related to six aspects of ADL. The performance of the individual determines the score, with a maximum of six for independent individual and minimum of zero for total dependence. The total score is the sum of "yes" answers, where six points represent complete independence in ADLs; four points, partially dependence; and 2 points, significant dependence ${ }^{(8)}$.

For the assessment of cognitive function, we applied the Mini-Mental State Examination (MMSE), a 30-point instrument, with scores ranging from zero (greatest degree of cognitive impairment) to 30 (best cognitive ability $)^{(9)}$.

The cutoff is often adjusted to the level of education, because a single cut may lose cases among people of higher educational level and generate false positives among those of lower educational level. In this study, we used the following cutoff scores: equal to thirteen for illiterates; eighteen for low and medium education (one to eight years); and twenty-six for high level of education (eight years or more) ${ }^{(10)}$.

To identify elderly people with hypertension, we searched the registers in the Hiperdia. Researchers completed the instruments in form of interview and without interfering in the answers. This interview took place in the homes of the elderly, in favorable schedules for them.

We analyzed data quantitatively and organized them in tables. For the characterization of elderly patients with hypertension, we used the Microsoft Word program, expressing absolute and percentage values. We verified the association between the ability to perform basic activities of daily living and the cognitive function with the scores of depression of the elderly with hypertension. We entered the data into the R software and submitted them to statistical analysis through the Fisher's Exact Test, considering the significance level of $5 \%(\mathrm{p}<0.05)$.

We submitted the research project to the evaluation of the Research Ethics Committee (CEP) of the Universidade José do Rosário Vellano - UNIFENAS, which approved it under protocol No. 264/2011. Data collection occurred from December 2011 to January 2012.

We informed all study participants about the research and requested them to sign the Informed Consent Form (ICF), according to Resolution 196/96 of the National Health Council. Furthermore, we informed the subjects about the guarantee of privacy, anonymity, and confidentiality of information, and that we would disseminate the results in scientific events and publish them. We also requested the authorization from the Local Secretary of Health of the city of Alfenas-MG, Brazil, which provided the records containing the information for this study.

\section{Results}

The results of this study identified 52 elderly patients with symptoms of depression, with 45 classified with symptoms of moderate depression and seven with symptoms of severe depression. We observed a predominance of depressive symptoms in females (22.1\%) and in those aged between 70-79 years $(22 \%)$ (Table 1$)$. As regard to profession, we found that 120 (69.76\%) were retired, 28 (16.27\%) were pensioners, and 24 (13.95\%) practiced some profession.

According to Table 1, the married people presented more symptoms of depression (13.9\%). As for the socio-demographic variables, we observed that education was the only one with a significant association with the presence of depressive symptoms. 
Table 1 - Characterization of elderly patients with hypertension that present symptoms of depression

\begin{tabular}{|c|c|c|c|}
\hline \multirow[t]{2}{*}{ Variables } & $\begin{array}{c}\text { Without } \\
\text { symptoms } \\
\text { of depres- } \\
\quad \text { sion } \\
\end{array}$ & $\begin{array}{c}\text { With symptoms } \\
\text { of depression }\end{array}$ & \multirow[t]{2}{*}{ p-value } \\
\hline & n (\%) & n (\%) & \\
\hline \multicolumn{4}{|l|}{ Gender } \\
\hline Male & $41(23.9)$ & $14(8.1)$ & \multirow{2}{*}{0.397} \\
\hline Female & $79(45.9)$ & $38(22.1)$ & \\
\hline \multicolumn{4}{|l|}{ Age group } \\
\hline $60-69$ & $65(37.8)$ & $21(12.2)$ & \multirow{3}{*}{0.253} \\
\hline $70-79$ & $39(22.7)$ & $22(12.8)$ & \\
\hline$\geq 80$ & $16(9.3)$ & $9(5.2)$ & \\
\hline \multicolumn{4}{|l|}{ Marital status } \\
\hline Married & $63(36.6)$ & $24(13.9)$ & \multirow{4}{*}{0.648} \\
\hline Single & $6(3.48)$ & $5(2.9)$ & \\
\hline Widowed & $44(25.6)$ & $20(9.3)$ & \\
\hline Divorced/separated & $7(4.1)$ & $3(1.7)$ & \\
\hline \multicolumn{4}{|l|}{ Education } \\
\hline Illiterate & $31(18.0)$ & $23(13.4)$ & \multirow{2}{*}{$0.021^{* *}$} \\
\hline Literate & $89(51.7)$ & $29(16.9)$ & \\
\hline \multicolumn{4}{|l|}{$\begin{array}{l}\text { Per capita monthly } \\
\text { income (Minimum } \\
\text { wage }^{*} \text { ) }\end{array}$} \\
\hline$<1$ & $44(25.6)$ & $24(13.9)$ & \multirow{3}{*}{0.441} \\
\hline $1-3$ & $72(41.9)$ & $26(15.1)$ & \\
\hline$>3$ & $4(2.3)$ & $2(1.16)$ & \\
\hline \multicolumn{4}{|l|}{ Home ownership } \\
\hline Yes & $111(64.5)$ & $47(27.3)$ & \multirow{2}{*}{0.762} \\
\hline No & $9(5.2)$ & $5(2.9)$ & \\
\hline \multicolumn{4}{|l|}{ Religious practice } \\
\hline Yes & $118(68.6)$ & $52(30.2)$ & \multirow{2}{*}{1.000} \\
\hline No & $2(1.2)$ & $0(0.0)$ & \\
\hline
\end{tabular}

In terms of per capita monthly income, 26 elderly patients with symptoms of depression received 1-3 minimum wages. Most seniors had a religion, and two had no religious practice (Table 1). With regard to the homeownership, we found that 159 (92.4\%) elderly were the unit's owner, of which 47 have symptoms of depression. As for hypertension, 160 (93\%) elderly were classified as independent; four (2.2\%) had partial dependence; and eight (4.8\%), total dependence (Table 2). By associating the variables "ability to perform ADLs" and "depression", we verified a statistically significant difference $(p=0.00095)$.
Table 2 - Association between the ability to perform ADLs and depression of elderly people with hypertension

\begin{tabular}{lcccc}
\hline $\begin{array}{l}\text { Dependence } \\
\text { level* }\end{array}$ & $\begin{array}{c}\text { Without } \\
\text { symptoms } \\
\text { of depres- } \\
\text { sion }\end{array}$ & $\begin{array}{c}\text { With } \\
\text { symptoms } \\
\text { of moderate } \\
\text { depression }\end{array}$ & $\begin{array}{c}\text { With } \\
\text { symptoms } \\
\text { of severe } \\
\text { depression }\end{array}$ & Total \\
\cline { 2 - 5 } & $\mathbf{n ( \% )}$ & $\mathbf{n ~ ( \% )}$ & $\mathbf{n ~ ( \% )}$ & $\mathbf{n ~ ( \% )}$ \\
\hline Independence & $117(68.0)$ & $38(22.1)$ & $5(2.9)$ & $160(93.0)$ \\
$\begin{array}{l}\text { Partial } \\
\text { Dependence }\end{array}$ & $1(0.5)$ & $3(1.7)$ & $0(0.0)$ & $4(2.2)$ \\
$\begin{array}{l}\text { Total } \\
\text { Dependence } \\
\text { Total }\end{array}$ & $2(1.2)$ & $4(2.4)$ & $2(1.2)$ & $8(4.8)$ \\
& $120(69.7)$ & $45(26.2)$ & $7(4.1)$ & 172 \\
F Application of Fisher's exact test, p-value=0.00095 & $(100.0)$ \\
\hline
\end{tabular}

Regarding the cognitive capacity, we can observe in Table 3 a deficit in 43 (25\%) of the elderly with hypertension. We found no statistically significant difference ( $p=0.1158)$ when associating the variables "cognitive function" and "depression".

Table 3 - Association between cognitive function and the presence of depression in patients with hypertension

\begin{tabular}{lcccc}
\hline $\begin{array}{l}\text { Cognitive } \\
\text { deficit* }\end{array}$ & $\begin{array}{c}\text { Without } \\
\text { symptoms of } \\
\text { depression }\end{array}$ & $\begin{array}{c}\text { With } \\
\text { symptoms } \\
\text { of moderate } \\
\text { depression }\end{array}$ & $\begin{array}{c}\text { With } \\
\text { symptoms } \\
\text { of severe } \\
\text { depression }\end{array}$ & Total \\
\cline { 2 - 5 } & $\mathbf{n ~ ( \% )}$ & $\mathbf{n ~ ( \% )}$ & $\mathbf{n ~ ( \% )}$ & $\mathbf{n ~ ( \% )}$ \\
\hline Sim & $27(15.8)$ & $12(6.9)$ & $4(2.3)$ & $43(25.0)$ \\
Não & $93(54.2)$ & $33(19.1)$ & $3(1.7)$ & $129(75.0)$ \\
Total & $120(70.0)$ & $45(26.0)$ & $7(4.0)$ & $172(100.0)$ \\
\hline * & & & &
\end{tabular}

\section{Discussion}

We found symptoms of depression in 30.2\% of the sample, which points to the important issue of studies that track depression, since this presents an increasing prevalence in society, generating negative consequences for the quality of life of affected individuals ${ }^{(5)}$. The association between hypertension and depression among the elderly in an outpatient referral clinic found a statistically significant 
difference by gender, becoming positive in men, unlike our results that found no association between gender and the presence of depressive symptoms ${ }^{(11)}$.

There is a complex relationship between depression and blood pressure (BP). The literature describes the prevalence of increased depression in people with hypertension. We believe that mechanisms related to the hyperactive sympathetic nervous system and genetic influences may be the underlying mechanisms in the association between depression and hypertension. Another obvious fact on the presence of depression is that it worsens the course of hypertensive disease, as well as the use of antidepressant medications, which may induce alterations in BP and complicate the treatment of people with hypertension ${ }^{(12)}$.

The association of depressive symptoms with incidence of hypertension is still controversial. A study mentions that the conclusion without conducting longitudinal studies in other populations is premature ${ }^{(13)}$.

It is worth mentioning that the findings of this study, regardless of such association, point to the need for research aimed at early detection of depression in elderly patients with hypertension and the association with cognitive function and functional capacity in order to prevent complications, given that the prevalence of depression cases among hypertensive patients in this study was higher than in another study $(20 \%)^{(3)}$. Furthermore, the investigation of new cases of depression among elderly patients with hypertension has benefits such as reducing costs associated with late treatment, and avoiding family stress and the risk of chronic conditions associated with functional and cognitive decline.

It is often difficult to diagnose depression in the elderly, since health professionals can associate the main symptoms with the aging process and the accumulation of diseases, which delays the diagnosis and worsens the case $\mathrm{e}^{(14)}$.

As regards to ADLs, most elderly were classified as independent for basic activities, but were often with hypertension and with partial or total dependence. It is worth highlighting that there is still little research on the functional performance of Brazilian hypertensive elderly patients with dementia, which limits comparisons of the results of this study with the literature.

When considering the socio-demographic characteristics of the sample, the results of this study were usually similar to those described in a study that also investigated depressive symptoms in elderly assisted at the FHSU. It is noteworthy that in our study, unlike that other study, there was a statistically significant association between education and symptoms of depression ${ }^{(4)}$, which highlights the importance of identifying depressive symptoms and evaluate the socio-economic and educational conditions of the elderly among the activities performed by health professionals.

By associating the presence of depressive symptoms with the ability to perform basic activities of daily living, we verified that depressive symptoms might worsen physical immobility, since the elderly depressed loses interest in self-care, harms the selfesteem, and increases the loss of interest in daily activities. A research that analyzed the functional capacity in hypertensive elderly patients compared with normotensive found no statistically significant difference between groups in relation to upper- and lower-limbs strength tests. This result may be because the group of hypertensive subjects participated in a hypertension care program, which encouraged them to physical activity ${ }^{(15)}$.

It is worth mentioning that, in the present study, we did not assess the physical activity of elderly people with hypertension; however, the FHSU assists these seniors and encourages them to physical activity as well as the control and treatment of hypertension.

Through this study, we could not identify any association between cognitive function and presence of depression among the elderly, though depression is part of the diseases that most cause progressive cognitive decline and loss of autonomy. Through the MMSE, we found in this study that a quarter of the elderly had cognitive decline, unlike the results of a study that 
also assessed the cognitive ability and found that $69 \%$ of elderly patients with hypertension had cognitive decline. This result may be due to the cutoff scores used by the researcher, with 20 points for illiterates and 24 for literate individuals. In the present study, we used 13 points for illiterates, 18 for individuals with one to eight years of education, and 26 for people with more than eight years of education. Furthermore, that study did not investigate the association with the presence of depression as in this research ${ }^{(16)}$.

Another study observed that uncontrolled hypertension is a risk factor for cognitive function, and can further increase the cognitive deficits when associated with other comorbidities, such as depression. These results point to the fact that hypertension accelerates the process of cognitive loss, given the deleterious effect on the cerebral white matter and on the cerebrovascular function ${ }^{(16-17)}$.

The presence of cognitive impairment, associated with depression, compromises the quality of life of elderly patients with hypertension, which makes essential the research of cognitive deficits by nurses, as active members of the health team for implementing health strategies.

As a limitation of this research, we highlight that the results obtained have a differential, because it is about elderly with hypertension registered in a FHSU. Therefore, they are probably more informed and clinically assisted, which may have contributed to a higher frequency of people capable of performing activities of daily living and the absence of cognitive impairment. Another limitation concerns the study design, because as it is a cross-sectional study, the measurements take place at a single time, without a follow-up of individuals.

\section{Conclusion}

According to the data in this study, we concluded that elderly patients with hypertension present depressive symptoms in a percentage higher than that found in the general population. We also observed that most of them are able to perform activities of daily living, and the absence of cognitive impairment.

We also emphasize the need to conduct longitudinal studies to evaluate the cognitive deficit in elderly hypertensive patients depressed for a long period.

A major challenge for society is to allow the elderly to remain inserted in the social context, actively and independently. It is necessary and urgent to implement public policies that encourage the development in number, efficiency, and effectiveness of Programs for the Prevention, Control and Treatment of Chronic Conditions, especially for hypertension and depression, thus enabling improvements in quality of life of the elderly, and preserving their cognition and independence in ADLs for as long as possible.

When it comes to elderly care, the role of nurses can go beyond the care in health services. Therefore, this study might contribute to the nursing professionals active in the FHSU, once it shows they are able to identify situations of disability, cognitive impairment, and symptoms of depression in elderly patients with hypertension, thus enabling the full access to their rights.

\section{Collaborations}

Silva PCS contributed to the conception of the study, analysis, interpretation of data, drafting the article, and final approval of the version to be published. Monteiro LA contributed to the conception of the study, data collection and interpretation, drafting the article, and final approval of the version to be published. Graciano ADS contributed to the conception of the study, data collection, and drafting the article. Terra FS contributed to the analysis, data interpretation, and drafting the article. Veiga EV 
contributed to drafting the article and final approval of the version to be published.

\section{References}

1. Ramos MP, Arend SC. O impacto da reforma da previdência social rural brasileria nos arranjos familiares: uma análise para entender a composiçao dos domicílios dado o aumento da renda dos idosos. Rev Bras Est Popul. 2012; 29(1):67-86.

2. Freitas EV. Tratado de geriatria e gerontologia. $2^{\mathrm{a}}$ ed. Rio de Janeiro: Guanabara Koogan; 2006.

3. Amaral GFd, Jardim PCBV, Brasil MAA, Souza ALL, Freitas HF, Taniguchi LM, et al. Prevalência de transtorno depressivo maior em centro de referência no tratamento de hipertensão arterial. Rev Psiquiatr. 2007; 29(2):161-8.

4. Fernandes MGM, Nascimento NFS, Costa KNFMC. Prevalência e determinantes de sintomas depressivos em idosos atendidos na atenção primária de saúde. Rev Rene. 2010; 11(1):19-7.

5. Sass A, Gravena AAF, Pilger C, Mathias TAF, Marcon SS. Depression in elderly enrolled in a control program for hypertension and diabetes mellitus. Acta Paul Enferm. 2012; 25(1):80-5.

6. Valcarenghi RV, Santos SSC, Barlem ELD, Pelzer MT, Gomes GC, Lange C. Changes in function/cognition and depression in institutionalized elderly who have suffered falls. Acta Paul Enferm. 2011; 24(6):828-33.

7. Souza DB, Serra AJ, Suzuki FS. Atividade física e nível de depressão em idosas. Rev Bras Ciênc Saúde. 2012; 16(1):3-6.

8. Lino VTS, Pereira SRM, Camacho LAB, Ribeiro Filho ST, Buksman S. Adaptação transcultural da Escala de Independência em Atividades da Vida Diária (Escala de Katz). Cad Saúde Pública. 2008; 24(1):103-12.
9. Trindade APNT, Barboza MA, Oliveira FB, Borges APO. Repercussão do declínio cognitivo na capacidade funcional em idosos institucionalizados e não institucionalizados. Fisioter Mov. 2013; 26:281-9.

10. Souza IM, Damiano Teixeira KM, Tavares Mafra SC, Tinôco ALA. Rastreamento cognitivo de idosos institucionalizados em instituições de longa permanência para idosos. Oikos. 2011; 22(2):3-18.

11. Duarte MB, Rego MAV. Comorbidade entre depressão e doenças clínicas em um ambulatório de geriatria. Cad Saude Publica. 2007; 23(3):691-700.

12. Quintana JF. A relação entre hipertensão com outros fatores de risco para doenças cardiovasculares e tratamento pela psicoterapia cognitivo comportamental. Rev SBPH [periódico na Internet]. 2011 [citado 2013 ago 30]; 14(1): [cerca de 15 p]. Disponível em: http:// pepsic.bvsalud.org/scielo.php?pid=S1516$-08582011000100002 \&$ script=sci_arttext

13. Delaney JA, Oddson BE, Kramer H, Shea S, Psaty BM, McClelland RL. Baseline depressive symptoms are not associated with clinically important levels. Hypertension. 2010; 55(2):408-14.

14. Prata HL, Alves Junior EDA, Paula FL, Ferreira SM. Envelhecimento, depressão e quedas: um estudo com os participantes do Projeto Prev-Quedas. Fisioter Mov. 2011; 24(3):437-43.

15. Santos CCC, Pedrosa R, Costa FA, Mendonça KMPP, Holanda GM. Análise da função cognitiva e capacidade funcional em idosos hipertensos. Rev Bras Geriat Gerontol. 2011; 14(2):241-50.

16. Birns J, Kalra L. Cognitive function and hypertension. J Hum Hypertens. 2008; 23(2):86-96.

17. Melo ROV, Martin JFV. Influência dos níveis pressóricos no desenvolvimento do déficit cognitivo. Rev Bras Hipertens. 2008; 15(1):37-8. 